\title{
Short Communication: Age and growth of elongated mudskipper, Pseudapocryptes elongatus (Cuvier, 1816) from Sundarbans, India
}

\author{
GOPALAN MAHADEVAN ${ }^{1, \boldsymbol{}}$, PALANIVEL BHARATHIRAJAN ${ }^{1}$, VELAYUTHAM RAVI ${ }^{1}$, \\ MOJTABA POULADI ${ }^{2}$, MARYAM MIRZAEI VAND KHANGHAH ${ }^{2}$ \\ ${ }^{1}$ Centre of Advanced Study in Marine Biology, Faculty of Marine Sciences, Annamalai University. Parangipettai-608 502, Tamil Nadu, India, \\ Tel.: +91-8870214112,`email: marinemahadevan@ gmail.com \\ ${ }^{2}$ Department of Fisheries, Faculty of Fisheries and Environmental Sciences, Gorgan University of Agricultural Sciences and Natural Resources. Gorgan, \\ Golestan, Iran
}

Manuscript received: 8 November 2018. Revision accepted: 2 December 2018.

\begin{abstract}
Mahadevan G, Bharathirajan P, Ravi V, Pouladi M, Mirzaei Vand Khanghah M. 2019. Short Communication: Age and growth of elongated mudskipper, Pseudapocryptes elongatus (Cuvier, 1816) from Sundarbans, India. Biodiversitas 20: 85-90. The estimation of age and mathematical expression of fish growth is complex and debated subject in fishery sciences. Growth parameters of elongated mudskipper, Pseudapocryptes elongatus were estimated based on the length frequency data using FiSAT II software (several tools such as Powell-Wetherall method, ELEFAN and von Bertalanffy growth estimates). Samples were collected from Sundarbans mangroves using gill and cast nets and by hand picking. The length-frequency (LFQ) of P.elongatus was recorded from January 2014 to December 2015 and the above tools estimated the growth parameters ( $\mathrm{L}_{\infty}, \mathrm{K}$ and $\mathrm{t}_{0}$ ) from the progression of LFQ modes through time. $\mathrm{L}_{\infty}$ and $\mathrm{K}$ values of males were $220.50 \mathrm{~mm}$ and $1.3 \mathrm{yr}^{-1}$, respectively and similarly, $\mathrm{L}_{\infty}$ and $\mathrm{K}$ values of females were $221.05 \mathrm{~mm}^{\mathrm{m}} \mathrm{and} 1.21 \mathrm{yr}^{-1}$, respectively. The $t_{0}$ values estimated for males and females were- 0.1915 years and- 0.1661 years, respectively. The estimated growth performance index $(\Phi)$ values for males and females of P. elongatus were 4.394 and 4.503 , respectively. The lifespan of both the sexes was found to be $4^{+}$years.
\end{abstract}

Keywords: Age and growth, Pseudapocryptes elongatus, FiSAT II, Sundarbans, India

\section{INTRODUCTION}

The Gobiidae is not only the largest family of the order Perciformes but also the species-rich family in fishes and also among vertebrates (Van Tassell 1998). The total number of genera is about 212 with roughly 1875 species. The five provisionally recognised subfamilies are Oxudercinae (Murdy, 1989), Amblyopinae (Hoese 1984; Birdsong et al. 1988) Sicydiinae (Pezlod 1993), Gobionellinae (Pezlod 1993) and Gobinnae (Birdsong et al. 1988; Pezlod 1993). The estimation of age and mathematical expression of fish growth is complex and debated subject in fishery sciences. Controversy still rages around the most appropriate means of age determination (Nedreaas 1990). Information on the age and growth of an organism is extremely important in understanding the nature of its stock, the role played by various year classes in the fishery constituted by the animal, the conditions required for optimum growth, the influence of environmental factors on growth, and also in comparing the rate of growth in different water bodies (Katselis et al. 2002).

The analysis of length-frequency data is a reliable way of obtaining age and growth parameters of fishes in a tropical region. Many computer-assisted methods exist for the analysis of length-frequency data of fish and shell fish such as LFSA (Sparre and Venema 1987), COMPLEAT
ELEFAN (Gayanilo et al. 1988), MULTIFAN (Fournier et al. 1990), FiSAT (Gayanilo and Pauly 1997) and LFDA (Kirkwood et al. 2001). Each method has its own strengths and inadequacies. The ELEFAN method is the most broadly used because it is easy to use, its utilization requests small preparing force, it doesn't require ordinariness in the appropriation of the informational collection utilized and the hypothesis behind it is straightforward.

Previously very few attempts were made to determine the age and growth of $P$. elongatus. Zhang et al. (1990) studied the age and growth of Boleophthalmus pectinirostris collected from the tidal mudflats of China. Washio et al. (1990) determined the age and growth of $B$. pectinirostris collected from the Midori River Japan. King (1995) predicted the population dynamics of the mudskipper P. barbarus from the Gross River estuary of Nigeria. $P$. elongatus is commonly called as elongate mudskipper and they are an important estuarine fish of east coast of India. Cai (1996) studied the population structure and reproductive biology of $B$. pectinirostris in Shenzhen bay located in China. Dinh et al. (2007) studied the biological aspects of $P$. lanceolatus distributed along the coastal areas of the Mekong Delta in Vietnam. Bucholtz et al. (2009) evaluated length-weight of the mudskipper $P$. elongatus in the Mekong Delta, Vietnam. So far no attempt was made to determine the age and growth of the 
mudskipper $P$. elongatus from Indian coastal waters, therefore the present study was carried out to determine the age and growth of this species in Sundarbans, India.

\section{MATERIALS AND METHODS}

Specimens of Pseudapocryptes elongatus were collected from Sundarbans mangroves (West Bengal, India) using scoop net (0.5-2 $\mathrm{mm}$ mesh size) and cast net $(6-8 \mathrm{~cm}$ mesh size $)$ and by hand picking $\left(88^{\circ} 18^{\prime} 10^{\prime \prime} \mathrm{E}\right.$ longitude and $21^{\circ} 42^{\prime} 30^{\prime \prime} \mathrm{N}$ latitude) for a period of two years, (January 2014 to December 2015) (Figure 1). The data were segregated sex-wise and the estimates were made separately for males and females. A total of 1151 specimens (527 males and 624 females) ranging from 6.2 $\mathrm{cm}$ to $19.7 \mathrm{~cm}$ TL males, $6.5 \mathrm{~cm}$ to $20.2 \mathrm{~cm}$ TL females were used for the present study (Figure 2). The total length was measured to the nearest millimeter $(0.1 \mathrm{~mm})$ and weight (W) was measured with $0.01 \mathrm{~g}$ accuracy.
Growth parameters were analyzed by ELEFAN with monthly length-frequency data (Wetherall 1986). The assigned ages at each length group were used for the estimation of the growth parameters $\left(\mathrm{L}_{\infty}, \mathrm{K}\right.$ and $\left.\mathrm{t}_{0}\right)$ according to von Bertalanffy (1938) growth formula:

$\left.\mathrm{Lt}=\mathrm{L}_{\infty}\left[1-\mathrm{e}^{\mathrm{K}}{ }^{(\mathrm{t}-\mathrm{t}} 0\right)\right]$

Where $\mathrm{L} \infty$ is the asymptotic length in $\mathrm{cm}, \mathrm{K}$ is the growth coefficient and $t_{0}$ is the length at age 0 . Growth performance index was calculated by the equation (Pauly and Munro 1984):

$\Phi=\log _{10} \mathrm{~K}+2 \log _{10} \mathrm{~L}_{\infty}$

Longevity can be estimated from the following equation (Pauly 1983):

$\mathrm{t}_{\max }=3 / \mathrm{K}$

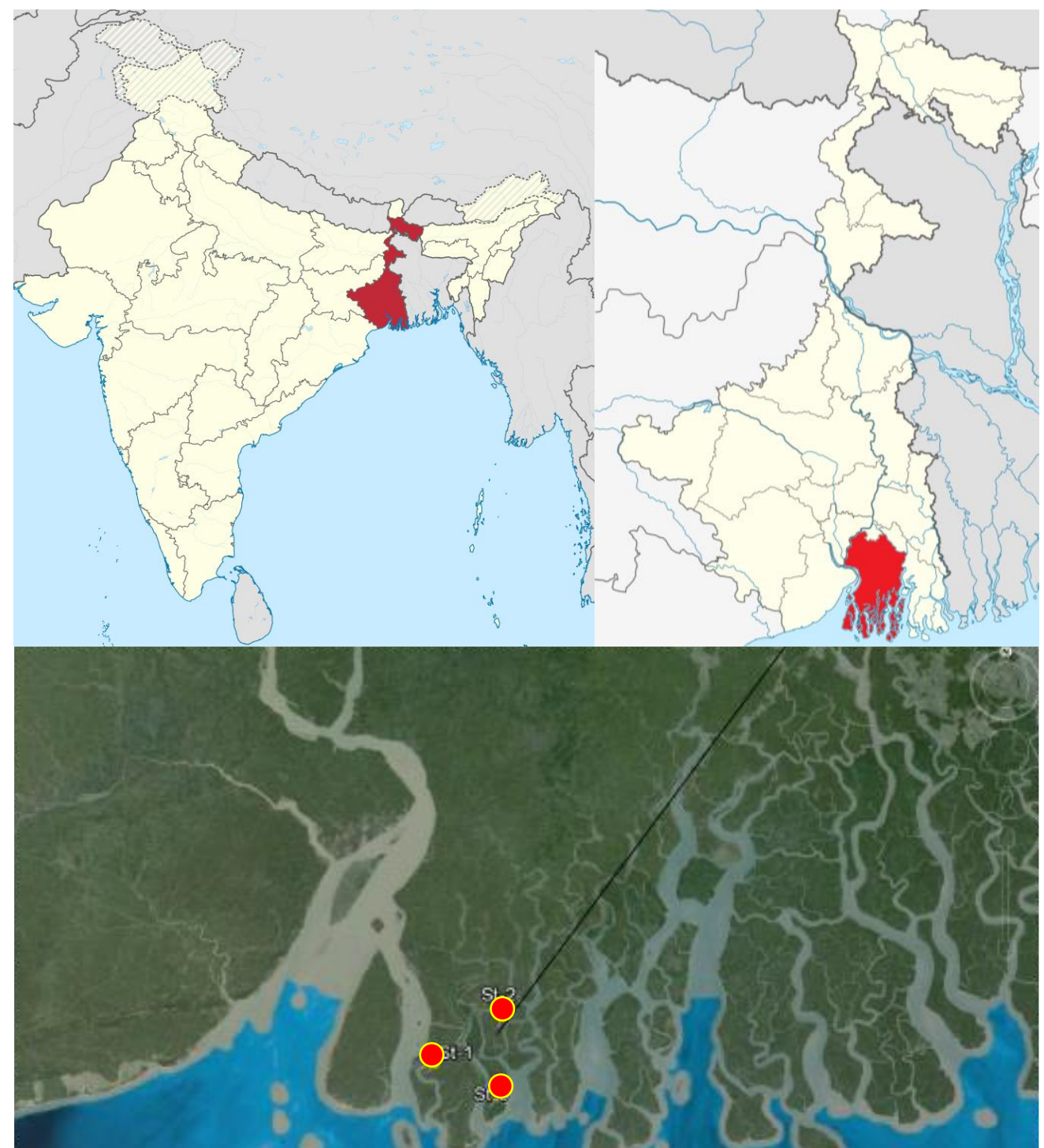

Figure 1. Sampling stations located in Sundarbans (West Bengal, India) during the study period 


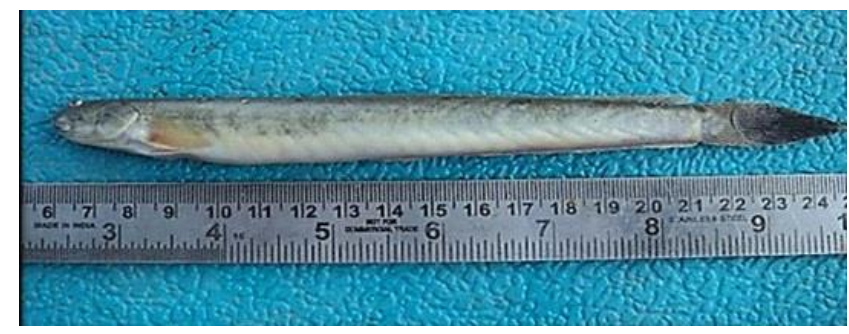

Figure 2. Pseudapocryptes elongatus (Cuvier 1816) collected from Sundarbans, India

\section{Statistical analysis}

Shapiro-Wilkes test was performed to check the normality of the data. The data were transmitted to $\log _{10}(\mathrm{x}$ +1 ) to remove heterogeneity of variances and normalize them. Data analysis was performed using Excel software (version 2010) and FiSAT II.

\section{RESULTS AND DISCUSSION}

No published information is available so far on the age and growth of $P$. elongatus from Indian waters. Hence the present work may be the first of its kind on this species. As the study of scales and otolith do not yield any conclusive result in the tropical climate and therefore the methods using length frequency data throws more light on the age and growth. Estimation of age and growth through indirect/statistical methods has its very own impediments especially when it is estimated by a single method. Hence in the present study, various methods have been used to get accurate results.

The small sized males $(6.2 \mathrm{~cm})$ and females $(6.5 \mathrm{~cm})$ were dominant during the post-monsoon season whereas the largest males $(19.7 \mathrm{~cm})$ and females $(20.2 \mathrm{~cm})$ were represented during pre-monsoon. The results of $\mathrm{L}_{\infty}$ and $\mathrm{Z} / \mathrm{K}$ (value of the total mortality coefficient) estimated by Powell-Wetherall method are shown in Figure 3 and Table 1. Estimated asymptotic lengths obtained for both males and females of $P$. elongatus were $227.13 \mathrm{~mm}$ and $242.29 \mathrm{~mm}$. The data points was found to lie almost along the line of equality, which indicates high degree of correlation $(\mathrm{r}=$ 0.999).

In the present study, the Wetherall method was used to estimate $\mathrm{L}_{\infty}$ and the value of the total mortality coefficient $\mathrm{Z} / \mathrm{K}$ from pooled samples in a time series of length frequency data; where $\mathrm{K}$ was determined to employ various routines of FiSAT II (ELEFAN I). This method allows for an objective extraction of growth parameters by using length-frequency data whenever representative samples are available from a fish population.

The lifespan of both males and females appear to be $4^{+}$ years as evident through the number of lines in the histogram (Figure 4). The estimated asymptotic length, growth rate and the goodness of fit index $(\mathrm{Rn})$ for both males and females of $P$. elongatus is given in Table $1 . \mathrm{L}_{\infty}$ and $\mathrm{K}$ values were $220.50 \mathrm{~mm}$ and $1.3 \mathrm{yr}^{-1}$ for males and $221.05 \mathrm{~mm}$ and $1.21 \mathrm{yr}^{-1}$ for females, respectively, whereas the $\mathrm{K}$-scan routines gave the values of $220.50 \mathrm{~mm}$ and 0.34 $\mathrm{yr}^{-1}$ for males and $220.50 \mathrm{~mm}$ and $0.28 \mathrm{yr}^{-1}$ for female respectively. The estimated $\mathrm{Rn}$ values for both males and females were 0.241 and 0.302 , respectively.

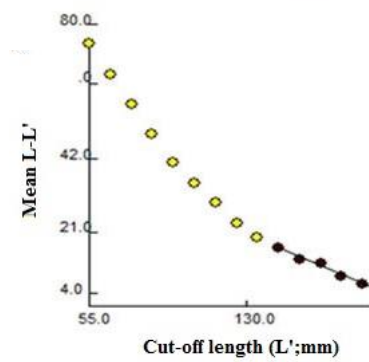

A

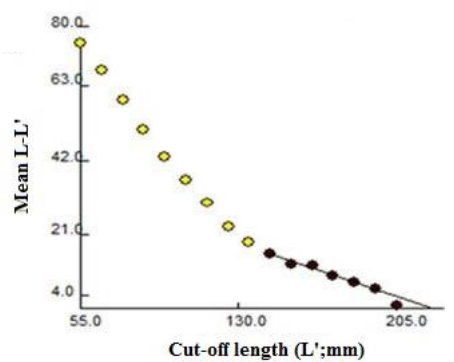

B
Figure 3. Powell-Wetherall plot of males (A) and females (B) of Pseudapocryptes elongatus

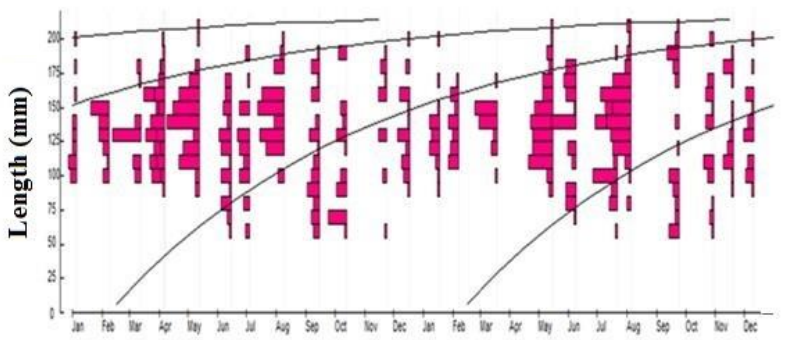

A

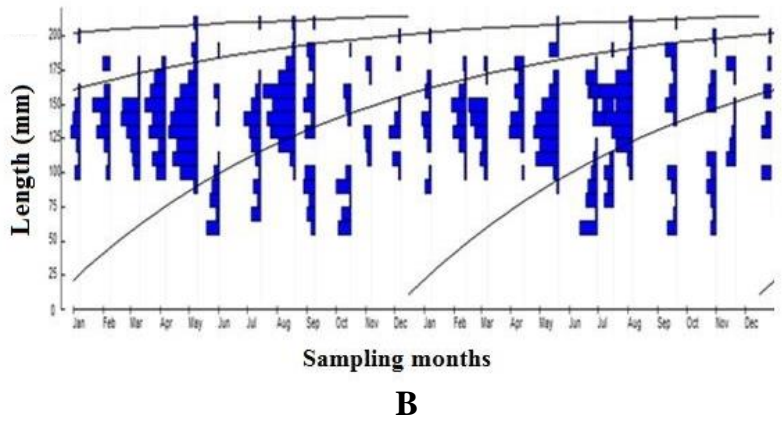

Figure 4. Growth curve derived using ELEFAN I for males (A) and females (B) of Pseudapocryptes elongatus

Table 1. Growth parameters of males and females of Pseudapocryptes elongatus obtained from different methods using length frequency data

\begin{tabular}{llllll}
\hline Method & Sex & $\begin{array}{l}\mathbf{L}_{\infty} \\
(\mathbf{m m})\end{array}$ & $\mathbf{Z / K}$ & $\begin{array}{l}\mathbf{K}\left(\mathbf{y r}^{-}\right. \\
\mathbf{1})\end{array}$ & $\begin{array}{l}\mathbf{R n} / \\
\text { Score }\end{array}$ \\
\hline Powell Wetherall & $\mathrm{M}$ & 227.13 & 3.98 & - & - \\
& $\mathrm{F}$ & 242.29 & 3.09 & - & - \\
ELEFAN I & $\mathrm{M}$ & 220.5 & - & 1.3 & 0.241 \\
(i) Automatic search & $\mathrm{F}$ & 221.05 & - & 1.21 & 0.302 \\
(ii) K-scan & $\mathrm{M}$ & 220.5 & - & 0.34 & 0.241 \\
& $\mathrm{~F}$ & 220.5 & - & 0.28 & 0.283 \\
Shepherd's method & $\mathrm{M}$ & 220.5 & - & 0.290 & - \\
K-scan & $\mathrm{F}$ & 221.05 & - & 0.910 & - \\
Response surface & $\mathrm{M}$ & 273.8 & - & 0.514 & - \\
& $\mathrm{F}$ & 220.5 & - & 1.01 & - \\
\hline
\end{tabular}


The estimated asymptotic length and growth rate for both males and females of $P$. elongatus by Munro's method using growth increment data are graphically represented in Figure 5. The asymptotic lengths obtained for both males and females of $P$. elongatus were $220.5 \mathrm{~mm}$ and the $\mathrm{K}$ values for males and females were 1.991 and $3.306 \mathrm{yr}^{-1}$, respectively. The results of the von Bertalanffy plot for the estimation of $\mathrm{K}$ and $\mathrm{t}_{0}$ for males and females of $P$. elongatus are shown in Table 2 and 3 and are graphically depicted in Figure 6. The values of the regression coefficient ' $a$ ', obtained were 0.201 for males and 0.249 for females. The slope ' $b$ ', which is equal to the $K$ value, was $1.21 \mathrm{yr}^{-1}$ for males and $1.32 \mathrm{yr}^{-1}$ for females. The $\mathrm{t}_{0}$ values estimated for males and females of were-0.1915 years and0.1661 years, respectively. The $\mathrm{L}_{\infty}$ values obtained were well above the maximum length $\left(\mathrm{L}_{\max }\right)$ values of $210.4 \mathrm{~mm}$ for males and $215.5 \mathrm{~mm}$ for females. The estimated asymptotic length in the present investigation utilizing different techniques didn't varied significantly and for males it was estimated as $220.5 \mathrm{~mm}$ and for females it was $221.05 \mathrm{~mm}$. K-scan routine in ELEFAN $\mathrm{I}$ and von Bertalanffy method estimated the best estimation of $\mathrm{K}$ for for males $\left(0.34 \mathrm{yr}^{-1}\right)$ and females $\left(0.28 \mathrm{yr}^{-1}\right)$. The foremost estimate of length at age 0 for males $(-0.1915)$ and females $(-0.1661)$ was predicted by von Bertalanffy method and similarly the best obtained goodness of fit index $(\mathrm{Rn})$ values for males and females of $P$. elongatus were 0.241 and 0.283 in the automatic scan method and 0.241 and 0.302 in K-scan method. Etim et al. (1996) studied age and growth of Periophthalmus papilio from African waters and found the asymptotic length of $19.39 \mathrm{~cm}$ and $\mathrm{K}$ value $0.51 \mathrm{yr}^{-1}$. Ravi (2000) studied age and growth of B. boddarti in Parangipettai waters and found the asymptotic length of $213.6 \mathrm{~mm}$ and growth coefficient of $0.4780 \mathrm{yr}^{-1}$. Mazlan and Rohaya (2008) reported a common $\mathrm{L}_{\infty}(\mathrm{cm})$ and $\mathrm{K}$ values for both male and female as $29 \mathrm{~cm}$ and $1.44 \mathrm{yr}^{-1}$ for P. scholosseri from Malaysian waters. Etim et al. (2002) estimated the age and growth of $P$. barbarus from the African coast. The $\mathrm{L}_{\infty}(\mathrm{cm})$ and $\mathrm{K}$ values were $21.6 \mathrm{~cm}$ and $0.55 \mathrm{yr}^{-1}$, respectively.

The variation in growth parameters in all the studies including the present one may be attributed to the spatial differences, sampling error, and methods used for the treatment of data. The $\mathrm{L}_{\infty}(\mathrm{cm})$ and $\mathrm{K}$ values obtained for $P$. elongatus from Asian Subcontinent include those of Tran et al. (2008) (26 cm and $0.65 \mathrm{yr}^{-1}$ ), Dinh et al. (2007) estimated the growth parameters $\mathrm{L}_{\infty}(25.9 \mathrm{~cm}), \mathrm{K}(0.66$ year ${ }^{-1} t_{0}-0.26$ year $\left.^{-1}\right)$. The longevity $\left(t_{\max }\right)$ of the goby was estimated to be 4.55 years. Dinh et al. (2015) reported the growth parameters of Parapocryptes serperaster, $\mathrm{L}_{\infty}(25.2$ $\mathrm{cm})$ and $\mathrm{K}\left(0.74\right.$ year $\left.^{-1}\right)$. Park et al. (2008) conveyed the von Bertalanffy growth parameters of Scartelaos gigas as $\mathrm{L}_{\infty} 179.36 \mathrm{~mm}, \mathrm{~K}\left(0.78 \mathrm{yr}^{-1}\right.$ and $\mathrm{t}_{0}-0.7762$. The results of the present investigation are similar to the observation from Vietnam waters made by Dinh et al. (2007). He opined that a female of $P$. elongatus tends to attain longer body lengths than males, especially in the mature sizes. This observation is consistent with the findings of the present work and it could be attributed to the fact that females have the ability to have a higher ovarian volume. This phenomenon is common in other species of mudskippers belonging to similar habitats as that of Parapocryptes serperaster in the Mekong delta (Dinh et al. 2015), P. scholosseri from Malaysian coast (Mazlan and Rohaya 2008), Boleophthalmus chinensis in the East China Sea (Tsukamoto et al. 1989), B. pectinirostris in the China coast (Washio et al. 1991) and P. elongatus in the Mekong delta (Dinh et al. 2015). The present investigation confirmed that males and females have much comparative growth rate, despite the fact that the $\mathrm{K}$ value of males were marginally higher.

Table 2. Predicted $\mathrm{K}$ and to values of Pseudapocryptes elongatus males using von Bertalanffy plot

\begin{tabular}{|c|c|c|c|c|}
\hline Age & Length $\left(L_{t}\right)$ & $\mathbf{L}_{\mathbf{t}} / \mathbf{L}_{\infty}$ & $1-\mathrm{L}_{\mathrm{t}} / \mathrm{L}_{\infty}$ & $-\mathbf{L N}\left(1-\mathbf{L}_{t} / \mathbf{L}_{\infty}\right)$ \\
\hline 1 & 60 & 0.2721 & 0.7279 & 0.3175 \\
\hline 2 & 75 & 0.3401 & 0.6599 & 0.4156 \\
\hline 3 & 150 & 0.6802 & 0.3198 & 1.1400 \\
\hline 4 & 200 & 0.907 & 0.093 & 2.375 \\
\hline
\end{tabular}

Note: $\mathrm{K}=\mathrm{b}=1.21 ; \mathrm{t}_{0}=(-\mathrm{a} / \mathrm{b})=-0.1915$

Table 3. Predicted $\mathrm{K}$ and $\mathrm{t}_{0}$ values of Pseudapocryptes elongatus females using von Bertalanffy plot

\begin{tabular}{|c|c|c|c|c|}
\hline Age & Length $\left(L_{t}\right)$ & $\mathbf{L}_{t} / \mathbf{L}_{\infty}$ & $1-\mathrm{Lt} / \mathrm{L}_{\infty}$ & $-\mathbf{L N}\left(1-\mathrm{L}_{\mathrm{t}} / \mathbf{L}_{\infty}\right)$ \\
\hline 1 & 60 & 0.2714 & 0.7286 & 0.3166 \\
\hline 2 & 79 & 0.3537 & 0.6463 & 0.4364 \\
\hline 3 & 167 & 0.7554 & 0.2446 & 1.4081 \\
\hline 4 & 210 & 0.95 & 0.05 & 2.995 \\
\hline
\end{tabular}

Note: $\mathrm{K}=\mathrm{b}=1.32 ; \mathrm{t}_{0}=(-\mathrm{a} / \mathrm{b})=-0.1661$

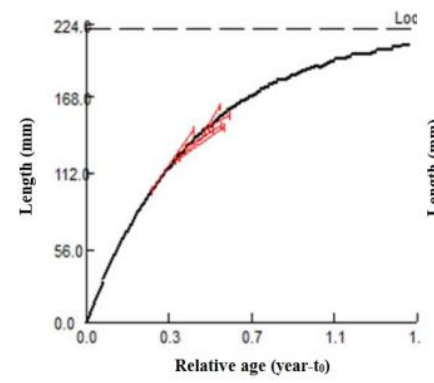

A

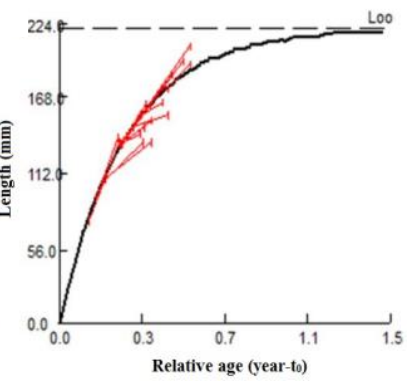

B
Figure 5. Munro's plot for males (A) and females (B) of $P$. elongatus

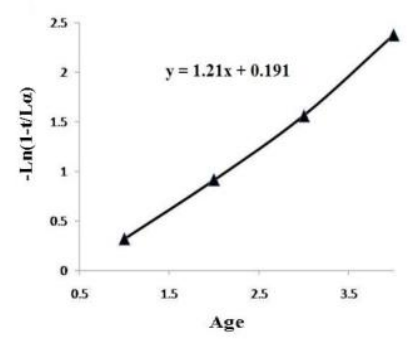

A

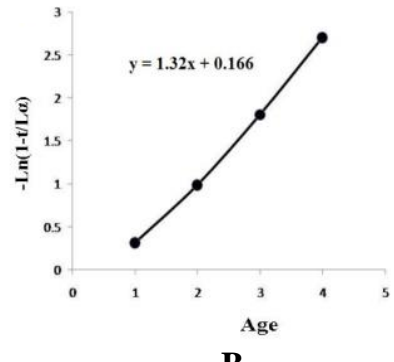

B
Figure 6. von Bertalanffy plot for males (a) and females (b) of Pseudapocryptes elongatus 
The growth comparison of fishes has to be estimated by multivariate perspective and hence $\mathrm{L}_{\infty}$ and $\mathrm{K}$ values are taken into consideration. The growth performance index $(\Phi)$ is a species-specific parameter, i.e., its values are usually similar within related taxa and have narrow normal distributions. Growth performance index $(\Phi)$ value is similar to a particular species even if it is collected from different regions (Pauly and Munro 1984). It is also an index of the accuracy and reliability of the growth parameters estimated for a species collected from different regions and growth parameters calculated using different methods (Bellido et al. 2000). Moreau et al. (1986) recommended $\Phi$ as the best growth parameter to estimate the reliability and accuracy of estimated growth parameters because it shows little variation among related taxa from different regions.

The estimated growth performance index $(\Phi)$ values for males and females of P. elongatus were 4.394 and 4.503, respectively. The growth performance index $(\Phi)$ in $P$. elongatus was slightly higher than other species. This may be because of the long caudal fin of the goby as compared with others. Swennen et al. (1995) also reported that this species has the longest caudal fin in relation to its total length $(20 \% \mathrm{TL})$. The growth performance index $(\Phi)$ of Periophthalmodon schlosseri was 3.01 (Mazlan and Rohaya 2008), P. elongatus was 2.64 (Tran et al. 2007), and Parapocryptes serperaster was 2.67 (Dinh et al. 2015).

Longevity $\left(\mathrm{t}_{\max }\right)$ of males and females of $P$. elongatus calculated from Pauly's equation was 4.071 and 4.196 years. On the other hand longevity $\left(t_{\max }\right)$ of males and females of $P$. elongatus calculated from the reverse, von Bertalanffy equation was 4.203 and 4.216 years, respectively. The estimated longevity of $P$. elongatus in this study was high and the age at first maturity was one year old. Comparing to previous work done on gobies, the maximum lifespan of $P$. elongatus is $4.55 \mathrm{yr}$ (Tran et al. 2007), but it is longer than the longevity of Gobius vittatus (2.94 yr) (Kovacic 2007), P. schlosseri (2.14 yr) (Mazlan and Rohaya 2008), and P. serperaster (4.05 yr) (Dinh et al. 2015). The variation of longevity among gobies could be due to geographic latitude, predation and fishing activities.

Despite the abundance of mudskippers in the Sundarbans, still they are poorly known and very few reports are available on its biology and ecology. The study of growth in P. elongatus under natural conditions is quite difficult and as such direct methods of age, a determination is impossible in fishes especially in tropical waters. Numerous indirect statistical methods could be used accurately in age and growth determination. In view of this fact, several methods were used in the present study to find out the age and growth of $P$. elongatus, including the routines of length frequency data, growth increment data and also length at age data. These methods were found to be quite useful and the growth parameters obtained here can be used for stock assessment of this species.

\section{ACKNOWLEDGEMENTS}

The authors wish to thank the Director and Dean, CAS Marine Biology and authorities of Annamalai University for providing the necessary facilities. The corresponding author is thankful to Ministry of Human Resource and Development [G4 (1)/1630/2013], New Delhi, India for financial support.

\section{REFERENCES}

Bellido JM, Pierce GJ, Romero JL, Míllan M. 2000. Use of frequency analysis methods to estimate growth of anchovy (Engraulis encrasicolus L. 1758) in the Gulf of Cadiz (SW Spain). Fish Res 48: 107-115.

Birdsong RS, Murdy EO, Pezold FL. 1988. A study of the vertebral column and median fin osteology in gobioid fishes with comments on gobioid relationships. Bull Mar Sci 42: 174-214.

Bucholtz RH, Meilvang AS, Cedhagen T, Christensen JT. 2009. Biological observations on the mudskipper Pseudapocryptes elongatus in the Mekong Delta, Vietnam. J World Aquac Soc 40: 711-723.

Cai Z. 1996. Population structure and reproductive characteristics of the mudskipper Boleophthalmus pectinirostris in Sehzen Bay, China Acta Ecol Sin Shengtai-Xuebas 16 (1): 77-82.

Dinh TD, Ambak MA, Hassan A, Phuong NT. 2007. Biology and population dynamics of the goby, Pseudapocryptes elongatus in the coastal mud flat areas of the Mekong Delta, Vietnam. Pak J Biol Sci 10: 3284-3294

Dinh QM, Qin JG, Tran D. 2015. Population and age structure of the goby Parapocryptes serperaster (Richardson, 1864; Gobiidae: Oxudercinae) in the Mekong Delta. Turk J Fish Aquat Sci 15: 345357.

Etim L, King RP, Udo MT. 2002. Breeding, growth, mortality and yield of the mudskipper Periophthalmus barbarus (Linnaeus 1766) (Teleostei: Gobiidae) in the Imo River estuary, Nigeria. Fish Res 56: 227-238.

Etim L, Brey T, Arntz W. 1996. A seminal study of the dynamics of a mudskipper (Periophthalmus papilio) population in the Cross river, Nigeria. Neth J Aquat Eco 30 (1): 79-96.

Fournier DA, Sibert JR, Majkowskiand J, Hampton J. 1990. Multifan a likelihood-based method for estimating growth parameters and age composition from multiple length frequency data sets illustrated using data for southern bluefin tuna (Thunnus maccoyii). Can J Fish Aquat Sci 47: 301-317.

Gayanilo FC, Soriano M, Pauly D. 1988. A draft guide to the complete ELEFAN. ICLARM Software 2. International Center for Living Aquatic Resources Management, Manila, Philippines.

Gayanilo FC Jr, Sparre P, Pauly D. 2005. FAO-ICLARM Stock Assessment Tools II (FiSAT II). Revised version. User's guide. FAO Computerized Information Series (Fisheries). No. 8, Revised version. Rome, FAO. 168 pp.

Hoese DF. 1984. Gobioidei: relationships. In: Moser HG, Richards WJ, Cohen DM, Fahay MP, Kendall JrAW, Richardson SL (eds.). Ontogeny and Systematics of Fishes. Spec. Publ. No. 1, Amer. Soc. Ichthy. and Herpet., Allen Press, Lawrence Kansas.

Katselis G, Koutsikopoulos C, Kaspiris P. 2002. Age determination and growth of leaping mullet, (Liza saliens) from the Messolonghi Etoliko Lagoon (Western Greece). Mediterr Mar Sci 3: 147-158.

King M. 1995. Fisheries Biology, Assessment and Management. Fishing News Books, Oxford University Press, Oxford, UK.

Kirkwood GP, Auckland R, Zara SJ. 2001. LFDA. Length Frequency Distribution Analysis, Version 5.0, MRAG Ltd, London U.K.

Kovacic M. 2007. Age structure, growth and mortality of the striped goby, Gobius vittatus (Gobiidae) in the northern Adriatic Sea. Sci Mar. 70: 635-641. 
Mazlan AG, Rohaya M. 2008. Size, growth and reproductive biology of the giant mudskipper, Periophthalmodon schlosseri (Pallas, 1770), in Malaysian waters. J Appl Ichthyol 24: 290-296.

Moreau J, Bambino C, Pauly D. 1986. A Comparison of Four Indices of Overall Growth Performance Based on 100 Tilapia Populations (Fam Cichlidae). In: Maclean JL, Dizon LB, Hosillo LV. (eds.). The First Asian Fisheries Forum, Asian Fisheries Society, Manila

Murdy EO. 1989. A taxonomic revision and cladistic analysis of the oxudercine gobies (Gobiidae: Oxudercinae). Rec Aust Mus Suppl 11 $1-93$.

Nedreaas K. 1990. Age determination of Northeast Atlantic Sebastes species. J Cons Intl Explor Mer 47: 208-230.

Park KD, Kim JK, Chang DS, Kim JI. 2008. Age and growth of mudskipper, Scartelaos gigas from Korea. Anim Cells Syst 12: $305-$ 311.

Pauly D, Munro JL. 1984. Once more on the comparison of growth in fish and invertebrates. ICLARM, Fishbyte 2: 21

Pauly D. 1983. Some simple methods for the assessment of tropical fish stocks. FAO Fisheries Technical Paper No. 234 (FIRM/234).

Pezold F. 1993. Evidence for the monophyletic Gobiidae. Copeia (3): 634 643.

Ravi V. 2000. Studies on eco-biology the mudskipper Boleophthalmus boddarti (Pallas, 1770) (Pisces: Gobiidae), Ph. D., Thesis, Annamalai University, India.
Sparre P, Venema SC. 1987. Computer programs for fish stock assessment. Length-based fish stock assessment (LFSA) for Apple II computers. FAO Fish. Tech. Pap. (101) Suppl. 2.

Swennen C, Ruttanadakul N, Haver M, Piummongkol S, Prasertsongscum S, Intanai I, Chaipakdi W, Yeesin P, Horpet P, Detsathit S. 1995. The five sympatric mudskippers (Teleostei: Gobioidea) of Pattani area, southern Thailand. Nat Hist Bull Siam Soc 42: 109-129.

Tran DD, Ambak MA, Hassan A, Phuong NT. 2007. Population biology of the goby Pseudapocryptes elongatus (Cuvier, 1816) in the coastal mudflat areas of the Mekong Delta, Vietnam. Asian Fish Sci 20: 165179.

Tsukamoto K, Seki Y, Oba T, Oya M, Wahashi MI. 1989. Application of otolith to migration study of Salmonids. Physiol Ecol Jpn 1: 119-140.

Van Tassell JL. 2011. Gobiiformes of the Americas. The biology of gobies. CRC Press, Science Publishers, pp.139-176.

Von Bertalanffy L. 1938. A quantitative theory of organic growth (inquiries on growth law II). Hum Biol 10: 181-213.

Washio M, Tsutsui M, Takita T. 1991. Age and growth of the mudskipper Boleophthalmus pectrinirosris distributed in the mudflats of Midori River, Kumamoto Prefecture. Nippon Suisan Gakkaishi, Bull Jap Soc Sci fish 57 (4): 637-644.

Wetherall JA. 1986. A new method for estimating growth and mortality parameters from length-frequency data. ICLARM, Fish byte 4: 12-14.

Zhang QY, Zhang J. 1988. On the feeding, growth and survival of larval mud skipper (Boloeophthalmus pectinirostris). J Fish 12: 203-211. 